\title{
Asuhan Keperawatan Klien dengan Fraktur
}

\section{Hanny Handiyani*}

Konsep asuhan keperawatan klien dengan fraktur sudah banyak yang telah membahasnya. Namun tidak ada salahnya diulas kembali sebagai sumber bacaan bagi perawat lapangan, agar praktik keperawatan yang dilaksanakan dapat berdasarkan ilmu keperawatan praktis. Trauma muskuskeletal, khususnya fraktur memerlukan pemberian asuhan keperawatan yang komprehensif. Asuhan terutama ditujukan untuk memenuhi kebutuhan dasar klien yang terganggu dan mencegah mengurangi komplikasi terutama terhadap immobilisasi. Pendidikan kesehatan juga dapat diberikan untuk mencegah cedera lebih lanjut sehingga klien secara bertahap dapat mengoptimalkan fungsi bio-psiko-sosio-spiritualnya.

Kata kunci: muskuloskeletal, cedera, deformitas, latihan, traksi, nyeri

The concept of nursing care for client with fracture has been discussed by many authors. But it is always interesting to discuss it as reference for nurses working in the hospital.

Musculoskeletal trauma, especially fracture requires a comprehensive nursing care. The purpose of nursing care is to meet the disturbed basic human need of the client and to prevent client from further complication caused by immobilization.

The purpose of health education is to prevent the impact of injury and to support the client to obtain the optimal level of bio-psycho-sosio-spiritual functioning.

Key words: musculoskeletal, injury, deformity, exercise, traction, pain 